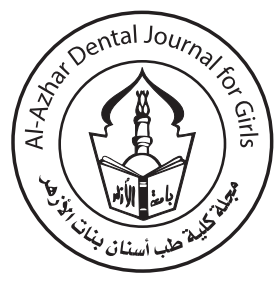

\title{
Educational Dental Program and Its Impact on Emergency Management of Traumatic Dental Injuries in Children
}

\author{
Nada A. Salem ${ }^{1 *}$, Mervat I. Fawzy ${ }^{2}$, Mohamed H. Mostafa ${ }^{3}$
}

Codex : 19/22.01

azhardentj@azhar.edu.eg

http://adjg.journals.ekb.eg

DOI: $10.21608 /$ adjg.2021.47750.1312

Pediatric Dentistry \& Orthodontics ( Pediatric Dentistry, Orthodontics)

\section{KEYWORDS}

Emergency,

Traumatic Dental Injuries,

General Dental Practitioner,

Avulsion, Teachers.

\begin{abstract}
ABSTRACT

Purpose: this study was conducted to design an educational dental program (campaign) for improvement of the awareness of parents, teachers and general dental practitioners regarding emergency management of traumatic dental injuries (TDI) in children and evaluate the impact of educational dental program (campaign) on level of knowledge about emergency procedure in TDI in children after 3 and 9 months. Subjects and Methods: A total number of 800 parents, 200 schoolteachers, and 200 general dental Practitioners' were randomly chosen. Evaluation of knowledge level for all groups was surveyed using a self-administered structured questionnaire, followed by awareness stage campaign to improve the level of knowledge of these groups of adults who would be the first line of defense in emergency TDI that can happen at home, school, and primary medical centers; then, the effect of the different awareness methods was evaluated among the groups. Result: A significant difference have been noticed in the level of knowledge in the groups after the educational dental program (campaign). Conclusion: educational dental program (campaign) play a main role in increasing level of awareness with emergency management of traumatic injuries in children,and cases prognosis.
\end{abstract}

\section{INTRODUCTION}

One of the main oral health complications which can cause a lot of suffering and stress is dental trauma, from a small enamel chip to

* Paper extracted from Doctor thesis titled "Educational Dental Program and its Impact on Emergency Management of (TDI) in Children".

1. Assistant Lecturer at Pedodontics and public Health Department, Faculty of Dental Medicine, October 6th Universit, Cairo, Egypt.

2. Professor of Endodontics Department, Faculty of Dental Medicine for Girls, Al-Azhar University, Cairo, Egypt.

3. Associate Professor and Head of Pedodontics and Oral Dental Health Department , Faculty of Dental Medicine for Girls, Al-Azhar University, Cairo, Egypt.

* Corresponding author email: dr_nada8833@yahoo.com 
huge orofacial damage assuming the displacement or avulsion of teeth ${ }^{(1)}$.

Avulsion is a serious dental injury and the success of the replantation depends on the time, using of an acceptable media to store the tooth until the time of replantation and handling the tooth with no touching to the root surface, thus increasing the possibility of tooth survival ${ }^{(2)}$.

The clinical management using many of diagnostic tools and techniques and suitable treatment can have an important role to increase the prognosis of a traumatic dental injuries (TDI) ${ }^{(3)}$. The prognosis highly hangs on proper emergency management, which hangs on the level of knowledge of care givers existing in the accident place before the beginning of dental treatment, like the children's parents and teachers ${ }^{(4)}$.

Reducing the following pain can be done by prevention of these injuries; therefore, the level of knowledge and awareness of the individuals who can be in contact with children at home and in school should be increased ${ }^{(5)}$.

Occasionally, TDI suddenly happen when general dental practitioners GDPs do not expect or even prepared for its management, that's why the stuff of emergency trauma centers and pedodontic clinics should have the awareness of the first aid procedure and proper emergency management to rescue the life of a child or even can diagnose the life threating condition; as well increasing the survival level of traumatized teeth because the time of treatment is responsible for the risk of tooth devitalization to occur ${ }^{(6-8)}$.

Most of the investigation clarify that dentists' have a shortage in the awareness and ability to manage TDI, therefore this investigation had been done to explore and increase the GDPs level of awareness about emergency procedures in TDI science, there is a few national published studies in the aspect in this point ${ }^{(9,10)}$.

\section{SUBJECTS AND METHODS}

\section{This cross sectional study was targeting:}

1. Total of 958 random sample of Egyptian parents.

2. Total of 147 random samples of Egyptian teachers who works in pre and primary (Grades 1-6) schools in different sectors who could read Arabic or English.

3. Total of 206 random sample of Egyptian general dental Practitioners "who participated in 3-day dental education program and was working or trains in primary health care. That was surveyed using a self-administered structured questionnaire.

Three types of questionnaires were developed and approved by specializes pedodontist and specializes Endodontists (members in Al-Azhar trauma center); the reliability and stability for the evaluation questionnaires were assessed using Cronbach Alpho and Common factor analysis. Questionnaires were developed in English as well as in Arabic language and before its distribution; a quick explanation about the objective of the investigation was given to the participants.

Following approval by the Research Ethics committee, Faculty of Dental Medicine for Girls, Al-Azhar University (REC code 18-086); different types of questionnaires for each group was distributed to all those participants who agreed to take apart in the investigation, investigator was available to make any required explanation of the subjects, the questionnaires were collected immediately after answering under the supervision of the investigator and compared with model answers.

\section{Stage one: (Evaluation of knowledge level)}

A-Questionnaire 1: (For parents) it was divided into three parts ${ }^{(11,12)}$. B- Questionnaire 2: (For teachers) it was divided into 4 parts ${ }^{(13)}$.The same questionnaire for the parents except the second section which have 6 questions about the teacher's 
role and responsibilities in the school. All of the147 questionnaires (before) for the teachers and the 958 questionnaires (before) for the parents were distributed during 9 months from April 2019 until March2020 .C- Questionnaire 3: (For general dental Practitioners) the questionnaire was divided into two parts personal and professional information where imaginary TDI cases were designed to evaluate their knowledge ${ }^{(14)}$. All of the 206 questionnaires were distributed during 9 months period: April 2019,July 2019 , and October 2019, and made sure that all of it were properly filled out.

\section{Stage two: (Awareness stage)}

Educational dental programs (Campaign) to improve the knowledge level .These programs were properly designed to accommodate with level of education, simplified, translated in Arabic (mother language) for the parents and teachers, and in scientific base for general practitioners to be sure that it had proper information according to the latest guidelines of American Association of Pediatric Dentistry (AAPD).

All the participants in all groups were educated by means of: lectures, power point presentations, mouth word, pins, the fliers, poster, banners, and specific first aid programs for each group.

Stage three: (evaluation of effect of the different awareness methods on the groups), was performed using the same questionnaires that were applied in aforementioned stages.

\section{RESULTS}

Frequencies and percentages used to describe statistics for all variables. Correlation coefficients was used to test the factor analysis of questionnaires ,Pearson correlation coefficient was used to analyse the relationship between knowledge score and age; while Spearman correlation coefficient used to evaluate the relationship between knowledge score and experience with TDI.

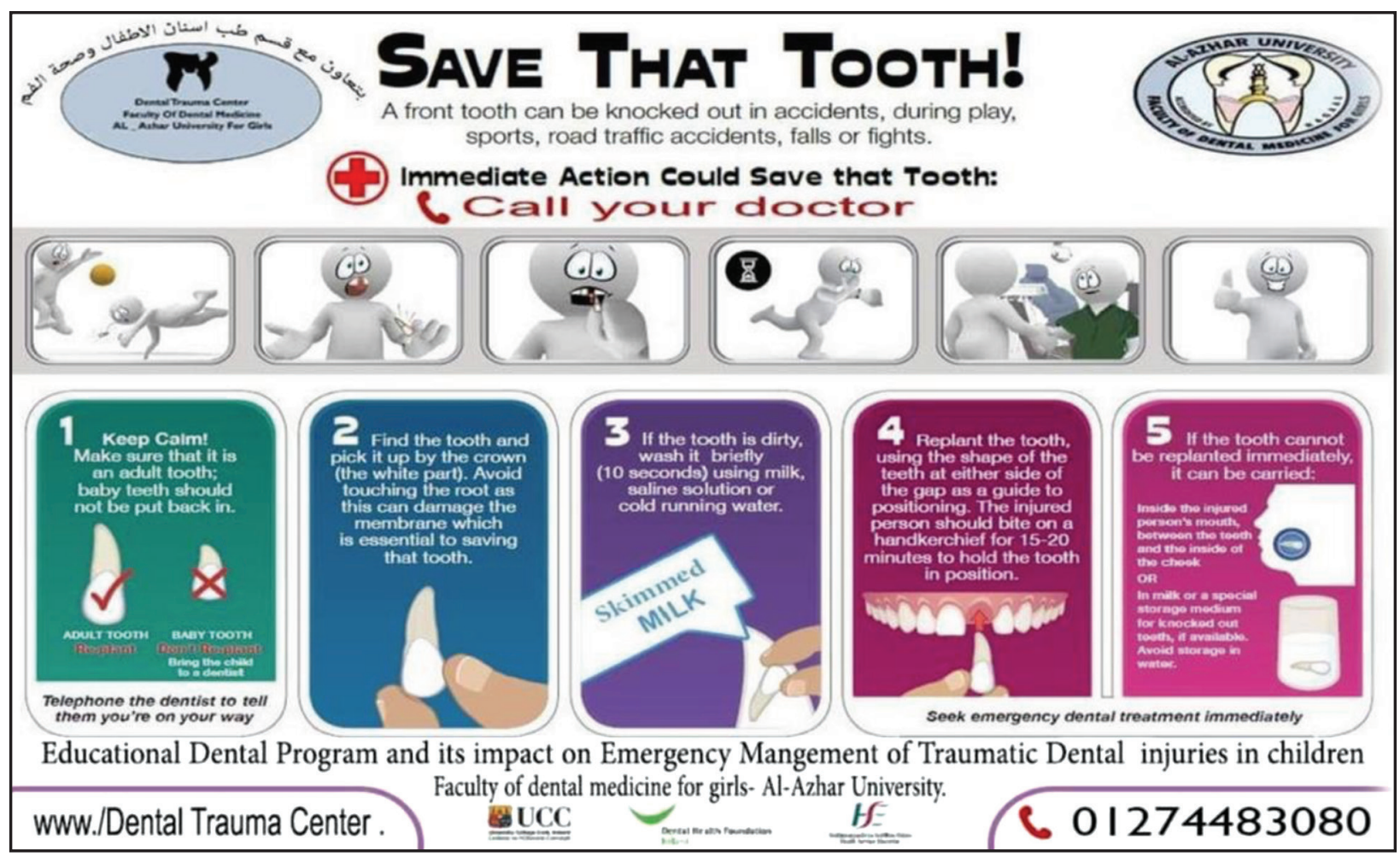

Figure(1) Poster and Fliers. 


\section{For parents and teachers:}

The questionnaire was completed by 958 participants, mean age 21.4248 (SD \pm 4.42$)$ years. Most of the participants were females (70.8\%) and only $28(29.2 \%)$ males. The parents had their own children (14.9\%); $3.9 \%$ one child, $7.8 \%$ two children, and $2.3 \%$ three children, $0.9 \%$ 3-4 children, $(85.1 \%)$ have no children.

The questionnaires were completed by 147 teachers, their age range was 20-53 years, and mean age was 28.48 years with S.D \pm 4.98 . Most of the participants were female teachers, $81.0 \%$ respectively; with the mean teaching years being 5.35years. Most of them had their own children (68.0\%); $9.5 \%$ one child, $43.5 \%$ two children, and $15.0 \%$ three children. Most of the teachers $(66.0 \%)$ approved responsible for children during activities, while $29.3 \%$ of them were responsible for one class.
Table (1) Knowledge and experience with TDI.

\begin{tabular}{cccc}
\hline Question & Answer & $\begin{array}{c}\text { Teachers } \\
\text { N (\%) }\end{array}$ & $\begin{array}{c}\text { Parents } \\
\text { N (\%) }\end{array}$ \\
\hline \multirow{2}{*}{$\begin{array}{c}\text { 1-Experience } \\
\text { with TDI ? }\end{array}$} & Yes & $45(30.6)$ & $256(26.7)$ \\
\cline { 2 - 4 } & No & $102(69.4)$ & $702(73.3)$ \\
\hline \multirow{2}{*}{$\begin{array}{c}\text { 2-Witnessing } \\
\text { TDI ? }\end{array}$} & Once & $106(72.1)$ & $699(73)$ \\
\cline { 2 - 4 } & Several times & $37(25.2)$ & $227(23.7)$ \\
\cline { 2 - 4 } & No & $4(2.7)$ & $32(3.3)$ \\
\hline \multirow{3}{*}{$\begin{array}{c}\text { 3-How did TDI } \\
\text { occur ? }\end{array}$} & Playing sports & $39(26.5)$ & $278(29.0)$ \\
\cline { 2 - 4 } & Wlaying in the & $18(12.2)$ & $133(13.9)$ \\
\cline { 2 - 4 } & school & $15(10.0)$ & $106(11.1)$ \\
\cline { 2 - 4 } & Fighting & $72(49)$ & $436(45.5)$ \\
\hline
\end{tabular}

$(N=147)$ teachers and $(N=958)$ parents.

Table (2) Management of dental injuries.

\begin{tabular}{|c|c|c|c|c|c|}
\hline Question & Answer & T before & T after & P before & $P$ after \\
\hline \multirow{4}{*}{$\begin{array}{c}\text { 1- What would you do in case of } \\
\text { TDI ? }\end{array}$} & Call the parents & $63(42.9)$ & $12(8.2)$ & $342(35.7)$ & $102(10.6)$ \\
\hline & Call the dentist & $77(52.4)$ & $127(86.4)$ & $562(58.7)$ & $818(85.4)$ \\
\hline & Call the doctor & $5(3.4)$ & $8(5.4)$ & $39(4.1)$ & $38(4.0)$ \\
\hline & Leave the child at home / School & $2(1.4)$ & 0000 & $15(1.6)$ & $0(0)$ \\
\hline \multirow{2}{*}{$\begin{array}{l}\text { 2- Do you know what is the } \\
\text { meaning of avulsion? }\end{array}$} & Yes & $40(27.2)$ & $120(81.6)$ & $251(26.2)$ & $858(89.6)$ \\
\hline & No & $107(72.8)$ & $27(18.4)$ & $707(73.8)$ & $100(10.4)$ \\
\hline \multirow{4}{*}{$\begin{array}{l}\text { 3-What would you do in case } \\
\text { of a completely extruded tooth } \\
\text { from its socket? }\end{array}$} & Throw the tooth away & $21(14.3)$ & $5(3.4)$ & $126(13.2)$ & $18(1.9)$ \\
\hline & Scrub the tooth & $3(2)$ & $6(4.1)$ & $7(0.7)$ & $18(1.9)$ \\
\hline & Wash the tooth with tap water & $29(19.7)$ & $112(76.2)$ & $127(13.3)$ & $738(77.0)$ \\
\hline & Wrap the tooth in a dry clean gauze & 94(63.9) & $24(16.3)$ & $698(72.9)$ & $184(19.2)$ \\
\hline \multirow{2}{*}{$\begin{array}{c}\text { 4-Did the primary teeth need } \\
\text { implantation? }\end{array}$} & Yes & $23(15.6)$ & $23(15.6)$ & $141(14.7)$ & $90(9.4)$ \\
\hline & No & $124(84.4)$ & $124(84.4)$ & $817(85.3)$ & $868(90.6)$ \\
\hline \multirow{8}{*}{$\begin{array}{l}\text { 5- The best media to place } \\
\text { the tooth in until you go to the } \\
\text { dentist. }\end{array}$} & Ice & $1(0.7)$ & $3(2.0)$ & $15(1.6)$ & $44(4.6)$ \\
\hline & Tap water & $6(4.1)$ & $1(0.7)$ & $22(2.3)$ & $5(0.5)$ \\
\hline & Tissue & $17(11.6)$ & $3(2.0)$ & $154(16.1)$ & $25(2.6)$ \\
\hline & Physiological solution & $45(30.6)$ & $36(24.5)$ & $280(29.2)$ & $139(14.5)$ \\
\hline & Cotton pad & $13(8.8)$ & 0 & $80(8.4)$ & $3(0.3)$ \\
\hline & Baby's mouth & $8(5.4)$ & $66(44.9)$ & $91(9.5)$ & $386(40.3)$ \\
\hline & Disinfection solution & $48(32.7)$ & $9(6.1)$ & $215(22.4)$ & $60(6.3)$ \\
\hline & Milk & $9(6.1)$ & $29(19.7)$ & $101(10.5)$ & $296(30.9)$ \\
\hline
\end{tabular}




\begin{tabular}{|c|c|c|c|c|c|}
\hline Question & Answer & T before & T after & P before & $P$ after \\
\hline \multirow{4}{*}{$\begin{array}{l}\text { 6-How would you hold a } \\
\text { completely extruded tooth? }\end{array}$} & By the crown & $64(43.5)$ & $127(86.4)$ & $374(39.0)$ & $878(91.6)$ \\
\hline & By the root & $25(17.0)$ & $10(6.8)$ & $174(18.2)$ & $38(4.0)$ \\
\hline & By the whole tooth & $13(8.8)$ & $7(4.8)$ & 131(13.7) & $33(3.4)$ \\
\hline & Would not touch it & $45(30.6)$ & $3(2.0)$ & $279(29.1)$ & $9(0.9)$ \\
\hline \multirow{2}{*}{$\begin{array}{l}\text { 7-Would you look after a } \\
\text { missing tooth fragment in the } \\
\text { site of the accident? }\end{array}$} & Yes & $73(49.7)$ & $140(95.2)$ & $606(63.3)$ & $923(96.3)$ \\
\hline & No & $74(50.3)$ & $7(4.8)$ & $352(36.7)$ & $35(3.7)$ \\
\hline \multirow{2}{*}{$\begin{array}{l}\text { 8-Can the dentist reattached } \\
\text { a fractured fragment to the } \\
\text { traumatized tooth? }\end{array}$} & Yes & $57(38.8)$ & $128(87.1)$ & $330(34.4)$ & $837(87.4)$ \\
\hline & No & $90(61.2)$ & 19(12.9) & $628(65.6)$ & $121(12.6)$ \\
\hline
\end{tabular}

$(N=147)(T)$ Teachers and $(N=958)(P)$ parents.

Table (3) Education about TDI

\begin{tabular}{|c|c|c|c|}
\hline Question & Answer & Teacher N (\%) & Parents N (\%) \\
\hline \multirow{2}{*}{$\begin{array}{l}\text { 1-Have you taken any } \\
\text { education about TDI? }\end{array}$} & Yes & $47(32.0)$ & $271(28.3)$ \\
\hline & No & $100(68.0)$ & $687(71.7)$ \\
\hline \multirow{6}{*}{$\begin{array}{l}\text { 2-How did you got information } \\
\text { about TDI ? }\end{array}$} & Consulting an expert & $41(27.9)$ & $265(27.6)$ \\
\hline & Consulting colleagues & $48(32.7)$ & $288(30.1)$ \\
\hline & Dental lectures & $69(46.9)$ & $440(45.9)$ \\
\hline & TV/ Radio shows & $51(34.7)$ & 294(30.7) \\
\hline & Internet & $72(49.0)$ & $475(49.6)$ \\
\hline & News Papers & $34(23.1)$ & $192(20.0)$ \\
\hline \multirow{2}{*}{$\begin{array}{l}\text { 3-Are you interested in taking } \\
\text { more information about TDI? }\end{array}$} & Yes & $113(76.9)$ & 754(78.7) \\
\hline & No & $34(23.1)$ & $204(21.3)$ \\
\hline \multirow{4}{*}{$\begin{array}{l}\text { 4-How do you like to be } \\
\text { educated about TDI? }\end{array}$} & Basic life support courses & $34(23.1)$ & $208(21.7)$ \\
\hline & Seminars and lectures by dentists at school & $58(39.5)$ & $441(46.0)$ \\
\hline & Online lectures & $41(27.9)$ & $220(23.0)$ \\
\hline & Don't Care & 14(9.5) & $89(9.3)$ \\
\hline
\end{tabular}

$(N=147)(T)$ Teachers and $(N=958)(P)$ parents.

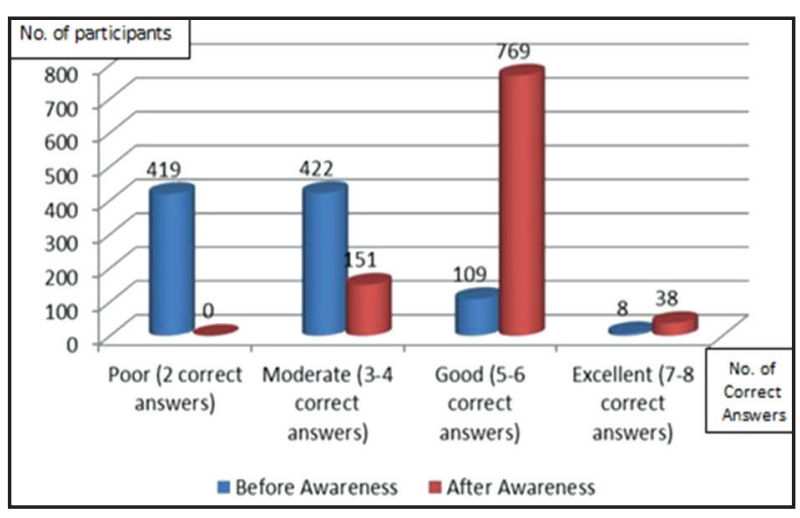

Figure (2) Bar chart representing mean and standard deviation values for parents knowledge score before and after awareness.
From (Fig.2) The result of paired t-test showed that, there was a significant difference in the mean knowledge score for parents after the educational programe (5.4708 with S.D 0.89; good), compared to their mean knowledge score before awareness (2.9071 with S.D 1.3; moderate), where $\mathrm{P}=0.000$.

From (Fig.3) The result of paired t-test showed that, there was a significant difference in the mean knowledge score for teacher after the educational programe (5.3537 with S.D 1.01227; good), compared to their mean knowledge score before awareness (2.9388 with S.D 1.55; moderate), where $\mathrm{P}=0.000$. 


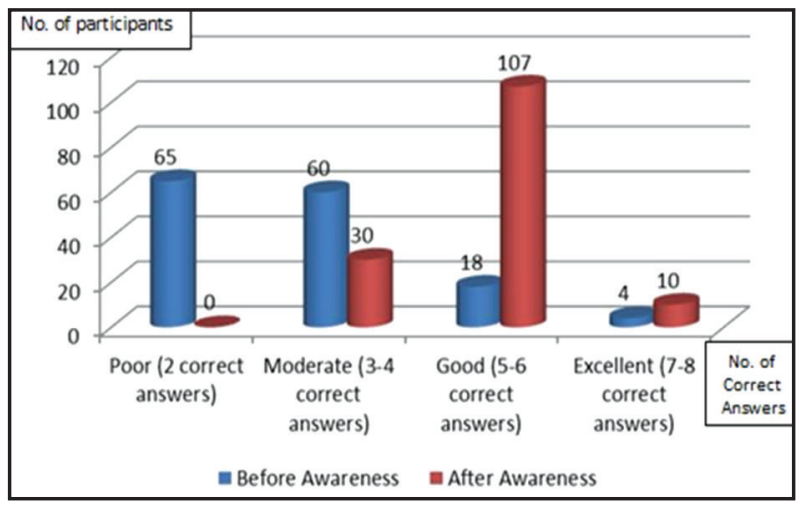

Figure (3) Bar chart representing mean and standard deviation values for teachers' knowledge score before and after awareness

\section{For general dental Practitioners}

The participants were 206 females, no males. Their age ranged from (19-38) years and the mean average of age was 25.11 with S.D 3.69.

There was significant difference in the correct answers in relationship with the attendance to educational courses about trauma injuries $(\mathrm{P}=0.024 \mathrm{a})$

There was a significant effect on the knowledge score for those who attended continuing educational courses of dental trauma $(\mathrm{P}=0.024 \mathrm{a})$. Also, there was a significant difference in the relation between GDPs' knowledge about TDI and their age ( $\mathrm{P}=0.01$, $\mathrm{r}=0.2$ ), as well as the relationship between level of knowledge and number of traumatic injuries cases managed in their practicing experience time was significant $(\mathrm{P}=0.01, \mathrm{r}=-0.2)$.

Table (4) Evaluation of the knowledge of GDPs about TDI; (N) is the number of GDPs, $(\%)$ is the percentage of participants who chose this answer, According to modified Ellis classification for TDI.

\begin{tabular}{|c|c|c|c|}
\hline \multirow{2}{*}{ Questions } & \multirow{2}{*}{ Answers } & $\begin{array}{l}\text { Before } \\
\text { N }(\%)\end{array}$ & $\begin{array}{l}\text { After } \\
\mathbf{N}(\%)\end{array}$ \\
\hline & & \multicolumn{2}{|c|}{ Total $\mathbf{N}=206$} \\
\hline \multirow{3}{*}{$\begin{array}{l}\text { 1- Class } 3 \text { crown fracture of } \\
\text { immature teeth after } 2 \text { days } \\
\text { medicament. }\end{array}$} & Pulpectomy. & $76(36.9)$ & $46(22.3)$ \\
\hline & apexogenises (correct). & $105(51)$ & 143(69.4) \\
\hline & Root canal treatment. & $25(12.1)$ & $17(8.3)$ \\
\hline \multirow{4}{*}{$\begin{array}{l}\text { 2- Class } 2 \text { crown fracture of } \\
\text { immature teeth medicament. }\end{array}$} & $\mathrm{Ca}(\mathrm{OH}) 2$ or (MTA) (correct). & 201(97.6) & 199(96.6) \\
\hline & Formalin. & $0(0)$ & $4(1.9)$ \\
\hline & Ferric sulfate. & $3(1.5)$ & $1(0.5)$ \\
\hline & Nothing. & $2(1.0)$ & $2(1.0)$ \\
\hline \multirow{3}{*}{$\begin{array}{l}\text { 3- Class } 2 \text { crown fracture } \\
\text { Immediate treatment. }\end{array}$} & Apexogenisis. & $28(13.6)$ & $11(5.3)$ \\
\hline & Glass-ionomer (GI) or composite dressing (correct). & $71(34.5)$ & 133(64.6) \\
\hline & 2-week then follow-up and final restoration. & $107(51.9)$ & $62(30.1)$ \\
\hline \multirow{3}{*}{$\begin{array}{l}\text { 4- Root fracture class } 5 \\
\text { treatment. }\end{array}$} & Right away repositioning, splinting, and follow-up (correct). & $116(56.3)$ & $132(64.1)$ \\
\hline & Right away repositioning, splinting RCT, & $50(24.3)$ & $33(16.0)$ \\
\hline & $\begin{array}{l}\text { Right away repositioning and follow-up after 2-week then } \\
\text { splinting. }\end{array}$ & $40(19.4)$ & 41(19.9) \\
\hline \multirow{3}{*}{$\begin{array}{l}\text { 5- In root fracture splinting } \\
\text { should take. }\end{array}$} & $1-2$ weeks. & $85(41.3)$ & $36(17.5)$ \\
\hline & More than 4 months 6. & $43(20.9)$ & $14(6.8)$ \\
\hline & 3-4 week (correct). & $78(37.9)$ & $156(75.7)$ \\
\hline \multirow{3}{*}{$\begin{array}{l}\text { 6-Time for endodontic } \\
\text { treatment in root fracture. }\end{array}$} & $\begin{array}{l}\text { Follow-up for 1y then RCT of coronal segment if necrosis } \\
\text { happens }\end{array}$ & $57(27.7)$ & $57(27.7)$ \\
\hline & $\begin{array}{l}\text { After 1w extirpation of pulp and RCT just for coronal } \\
\text { segment. }\end{array}$ & $57(27.7)$ & $32(15.5)$ \\
\hline & $\begin{array}{l}\text { After first visit Extirpation of pulp and place medication (caoh) } \\
\text { for } 1 \mathrm{w} \text { and finally RCT for all tooth segments. (correct). }\end{array}$ & $92(44.7)$ & $117(56.8)$ \\
\hline
\end{tabular}




\begin{tabular}{|c|c|c|c|}
\hline \multirow{2}{*}{ Questions } & \multirow{2}{*}{ Answers } & $\begin{array}{l}\text { Before } \\
\text { N }(\%)\end{array}$ & $\begin{array}{c}\text { After } \\
\mathbf{N}(\%)\end{array}$ \\
\hline & & \multicolumn{2}{|c|}{ Total N=206 } \\
\hline \multirow{3}{*}{ 7- Treatment in intrusion. } & Right away orthodontic repositioning & $85(40.3)$ & $35(17.0)$ \\
\hline & $\begin{array}{l}\text { Wait } 3 \mathrm{w} \text { for spontaneous eruption and if no movement } \\
\text { happen, extrusion orthodontic ally(correct) }\end{array}$ & $106(51.5)$ & $159(77.2)$ \\
\hline & $\begin{array}{l}\text { Wait } 3 \mathrm{w} \text { for spontaneous eruption and if no movement } \\
\text { happens do extrusion surgically. }\end{array}$ & $17(8.3)$ & $12(5.8)$ \\
\hline \multirow{3}{*}{ 8- Treatment of extrusion. } & Right away repositioning and splinting(correct) & $171(83)$ & $185(89.8)$ \\
\hline & Grinding teeth off from occlusion and splinting & $32(15.5)$ & $13(6.3)$ \\
\hline & Allow for spontaneous repositioning & $3(1.5)$ & $8(3.9)$ \\
\hline \multirow{3}{*}{$\begin{array}{l}\text { 9- management procedures } \\
\text { for avulsed mature teeth with } \\
\text { more than } 1 \mathrm{~h} \text { dry-time. }\end{array}$} & $\begin{array}{l}\text { Excavate necrotic tissue and dissolve the blood clot from } \\
\text { socket by saline wash, soak in } 25 \% \text { sodium fluoride, RCT, } \\
\text { replantation and flexible splinting, give the patient antibiotic } \\
\text { therapy .(correct) }\end{array}$ & $93(45.1)$ & $139(67.5)$ \\
\hline & $\begin{array}{l}\text { Excavating necrotic tissue, replantation then flexible } \\
\text { splinting, give the patient antibiotic therapy. }\end{array}$ & $47(22.8)$ & $29(14.1)$ \\
\hline & $\begin{array}{l}\text { Soak in } 25 \% \text { sodium fluoride, RCT, replantation and flexible } \\
\text { splinting, describe antibiotic treatment for patient. }\end{array}$ & $66(32.0)$ & $38(18.4)$ \\
\hline \multirow{3}{*}{$\begin{array}{l}\text { 10- Emergancy management } \\
\text { procedures for avulsed tooth } \\
\text { at the place of accident. }\end{array}$} & $\begin{array}{l}\text { Replantation right away, and if it is impossible, the best } \\
\text { media to store tooth is in the patient's saliva and go to the } \\
\text { dentist immediately. (correct) }\end{array}$ & $123(59.7)$ & 190(92.2) \\
\hline & $\begin{array}{l}\text { the best media to store tooth in is saline and go to the dentist } \\
\text { within } 1 \mathrm{~h}\end{array}$ & $24(11.7)$ & $3(1.5)$ \\
\hline & $\begin{array}{l}\text { the best media to store tooth in is milk and go to the dentist } \\
\text { within } 1 \mathrm{~h} \text {. }\end{array}$ & $59(28.6)$ & $13(6.3)$ \\
\hline \multirow{2}{*}{$\begin{array}{l}\text { 11- What will you do when the } \\
\text { patient come to your clinic? }\end{array}$} & $\begin{array}{l}\text { Replantation if not performed before, splinting, antibiotic } \\
\text { therapy (correct). }\end{array}$ & $141(68.4)$ & $194(94.2)$ \\
\hline & $\begin{array}{l}\text { Vitality test, RCT, x-ray, flexible splinting, describe antibiotic } \\
\text { for } 7 \text { days. }\end{array}$ & $65(31.6)$ & $12(5.8)$ \\
\hline \multirow{3}{*}{$\begin{array}{l}\text { 12- Avulsed teeth which were } \\
\text { immediately replanted should } \\
\text { be splinted for. }\end{array}$} & 7-10 days. (correct) & $105(51.0)$ & $133(64.6)$ \\
\hline & 2 months. & $97(47.1)$ & $62(30.1)$ \\
\hline & 4 months. & $4(1.9)$ & $11(5.3)$ \\
\hline \multirow{3}{*}{$\begin{array}{l}\text { 13- When will you do } \\
\text { endodontic treatment? }\end{array}$} & At emergency first visit. & $45(21.8)$ & $9(4.4)$ \\
\hline & $\begin{array}{c}\text { replantation then after 7-10 days before removing of } \\
\text { splinting. (correct) }\end{array}$ & $83(40.3)$ & $169(82.0)$ \\
\hline & If there was any necrosis after removing of splinting. & $78(37.9)$ & $28(13.6)$ \\
\hline \multirow{2}{*}{$\begin{array}{l}\text { 14- In a 4-yearold child will } \\
\text { you replant the avulsed tooth? }\end{array}$} & No .(correct) & $136(66.0)$ & $182(88.3)$ \\
\hline & Yes. & $70(34.0)$ & $24(11.7)$ \\
\hline
\end{tabular}

From (Fig.4) The result of paired t-test showed that, there was a significant difference in the mean knowledge score for parents after the educational programe (10.8301 with S.D 1.33810; good), compared to their mean knowledge score before awareness (7.6990 with S.D 1.83109; moderate), where $\mathrm{P}=0.000$.

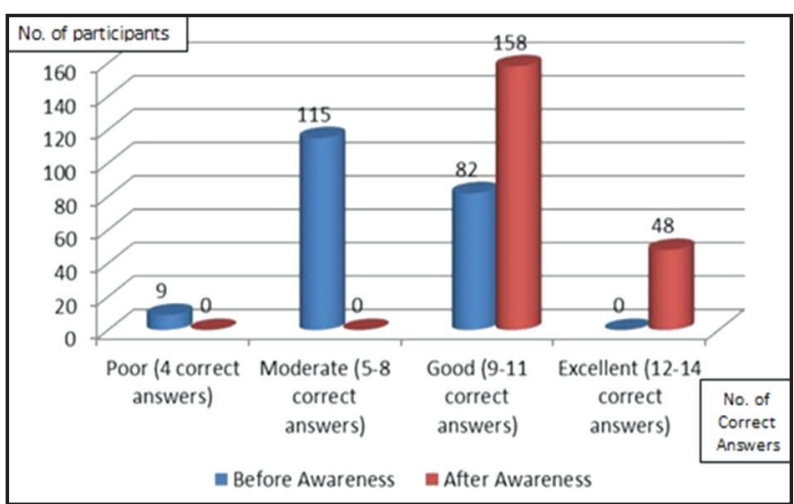

Figure (4) Bar chart representing comparison between before and after awareness. 


\section{DISCUSSION}

\section{For teachers and parents:}

The places with the greatest prevalence of the traumatic dental injuries (TDI) happening in children are schools, home, club, or street; that's why good awareness of emergency management procedures for parents and teachers is a must ${ }^{(14)}$.

Contact the dentist at the emergency time to take management procedures of the fractured tooth was chosen by $(52.4 \%)$ of the teachers and $(58.7 \%)$ of the parents. As wrong management may affect the treatment of TDI, this had been described in the dental educational course which in turn improved the results to $86.4 \%$ and $85.4 \%$, regarding teachers and parents respons, respectively.

The time taken by the patients to go to the dentist from the site of the accident especially in case of avulsion, as well as proper storage media are mandatory for prognosis and survival of the avulsed tooth ${ }^{(15)}$. Incorrect handling and long time out of the oral cavity may cause deformation of periodontal ligament, root resorption and may lead to ankylosis and tooth $\operatorname{loss}^{(9)}$. Therefore, replantation right away after complete extrusion from the socket is a must; however previous investigation showed that teachers' hate this point ${ }^{(16)}$

In the question about how to manage a completely extruded tooth from its socket, $63.9 \%$ and $72.9 \%$ of the teachers and parents respectively,would hold the tooth wrong and wrap it in a dry gauze, which could lead to permanent distortion for the periodontal ligament. The results are like those found in an investigation conducted in another country ${ }^{(17)}$. Only a few numbers of teachers and parents $(6.1 \%$ and $10.5 \%$ respectively) would place the tooth in milk, the International Association of Dental Traumatology considers it as a good storage medium for avulsed tooth ${ }^{(18)}$; that have been improved after the educational program (campaign) $(19.7 \%$ and $30.9 \%$ respectively) such finding is in accordance with an Indian prospective intervention study, that evaluated the effect of the informative promotion programs to improve the knowledge and awareness of school teachers. ${ }^{(19)}$.

Fractured tooth fragment can be reattached to traumatized tooth by dentist in order to preserve tooth vitality, arch integrity, esthetic, and functioning reasons.In ourstudy, $(50.3 \%)$ of teachers and $(36.7 \%)$ of parents would not look in the site of the accident for the missing part, also (61.2\%) of teachers and $(65.6 \%)$ of parents thought that attachment of this fragment to the tooth was not a treatment option. However, their knowledge had been improved after the educational program (campaign) into $(95.2 \%$ and $96.3 \%$ respectively) and (87.1\%and $87.4 \%$ respectively).A similar results had been found in an investigation measuring teachers' awareness about right management procedures of TDI ${ }^{(20)}$.

\section{For general dental Practitioners}

Close to half of participants said that they occasionally $(47.6 \%)$ or rarely $(20.4 \%)$ meet TDI in their daily work. That accommodate with the results of other investigations that said that traumatic injuries happen infrequently and at occasions when general practitioners are not ready for emergency management procedure ${ }^{(19-23)}$.

Before the beginning of the educational program, the practitioners" level of knowledge was moderate, just as reported in previous investigations; and had been improved to good by having the educational program which stressed on the week points found in the before questionnaires, using the latest guide lines of AAPD ${ }^{(24,25)}$.

According to the recent AAPD guidelines on the management procedures of complicated crown fracture (mod. Eliss class 3 ) in immature teeth With open apex more than $2 \mathrm{~mm}$, partial pulpotomy is the proper treatment or when there was untreated exposure for more than $24 \mathrm{~h}{ }^{(26)}$. However, the results of this investigation showed that only $51.0 \%$ of GDPs chose this answer in their questionnaire. Apparently, dentists feel less confident in providing 
emergency treatment of such complex case in immature teeth, which was also reported by an earlier study that analyzed correlation between dental trauma education and knowledge perception in the emergency treatment of complicated crown fracture among Flemish dental practitioners (27); but, the awareness after educational program was improved, that $69.4 \%$ of GDPs chose the right answer. While the best treatment for a crown fracture with pulp involvement of teeth with close apex is root canal treatment (RCT) in accordance with the recent guidelines of the International Association of Dental Trauma (IADT) ${ }^{(28)}$.

Dentists believed that root fractures must be immediately repositioned and splinted (56.3\%) but just (37.9\%) knew that its period is 3 to 4 weeks; most of them (41.3\%) thought that the normal 1-2 week period is enough. This is accommodating with the study which said that the rapid treatment and splinting of the root segments in one line improved the prognosis ${ }^{(29)}$.

A percentage of $(44.7 \%)$ of the participants had chosen that inter appointment calcium hydroxide dressing followed by RCT confined to the coronal segment is the best treatment procedure that's was corrected in the educational program and dentists' knowledge was improved, that $56.8 \%$ had chosen that the correct answer is follow-up for $1 \mathrm{y}$ then (RCT) of coronal segment if necrosis happens .

Those who chose to wait spontaneous re-eruption of intruded teeth with open apex was $51.5 \%$ of the participants., active repositioning of the teeth with open apex either with orthodontic or surgical way affect the healing prognosis of the tooth. On the other hand, outcome of the surgical and orthodontic repositioning in a case of sever intrusive luxation more than $7 \mathrm{~mm}$ give good results ${ }^{(30)}$, that have been mentioned in the educational program which improved the dentists' knowledge and (77.2\%) of the participants chose the correct answer.

As for extrusion of permanent tooth with open apex case, $(83 \%)$ of the participants had chosen the correct answer that was reposition it right away and splinting. Tooth maturation at the time of TDI, the extra-alveolar time and suitable storage medium are the most important factors for success of a replantation ${ }^{(28,31)}$, and the correct answer had been chosen more by the participants after the educational program $(89.8 \%)$. Similar results had been found in another investigation. ${ }^{(32,34)}$

As regards the treatment of avulsed teeth with close apex in an adult patient with more than $1 \mathrm{~h}$ of extra-oral dry time, $(45.1 \%)$ had chosen the right answer. In TDI management guidelines of IADT, the treatment of choice for avulsed teeth with close apex in more than $1 \mathrm{~h}$ of extra-oral time is removing the necrotic tissue, RCT, removing the blood clot from the socket by saline wash, soak it in $25 \%$ sodium fluoride, replantation, splinting , Antibiotic prescribtion ${ }^{(33)}$, and soft diet intake for 1 week $^{(28)}$. The correct answer had been chosen more by the participants after the educational program (67.5\%) and that result is similar to those found in other investigation ${ }^{(34)}$.

Time is the most important factor in the treatment of TDI that can directly affect the prognosis ${ }^{(35)}$, and most of GDPs had chosen to replant the avulsed tooth at the accident place $123(59.7 \%)$, than waiting until arrive to the dental office and that knowledge was improved more by the educational program 139(67.5\%).

Getting a professional emergency managementat the site of accident is mandatory, that would decrease the time between avulsion and replantation, and Consequently decrease the risk of having internal and external root resorption ${ }^{(35,36)}$. $51 \%$ of GDPs chose the answer to splint avulsed teeth for 7 to 10 days, which was higher in comparison with other studies were only $10-30 \%$ had chosen this answer ${ }^{(15,22)}$.

$136(66.0 \%)$ of GDPs chose the answer that they would never do replantation for primary tooth, result was improved by the educational program to $182(88.3 \%)$ which is consistent with 
the current guidelines and recommendations of the IADT ${ }^{22}$. Moderate level of awareness was seen by investigating GDPs. That's why a strong plan is important to keep all the dentists updated and increase their knowledge level specially toward TDI ${ }^{(23)}$. Approved guidelines were sent in the form of mails, posters and educational program about emergency management of TDI to increase GDPs level of knowledge ${ }^{(36)}$.

\section{CONCLUSION}

1. The teachers and parents awareness about the first aid emergency management procedures in TDI in Egypt was not enough, and had been improved by receving a dental educational program.

2. Practical experiences with trauma injuries in the daily work have a direct relation with dentists' knowledge, which had been improved by the special dental educational programs (campaign) to increase the level of professional information and publishing the culture of using the Association of Pediatric Program Directors (APPD) guideline among all GDPs.

\section{ACKNOWLEDGMENT}

The authors are grateful to all the participants that took part in this study. We also want to thank the Faculty of Dental Medicine for Girls, Al-Azhar University, Pedodontics and Oral Dental Health department and members of Al-Azhar trauma center for giving approval and supporting to this study.

\section{RECOMMENDATIONS}

At the end, specialized centers for TDI can be established in different cities with trained staff to offer 24-h services, especially for complicated cases. These centers must be connected to GDPs of the city and they should be able to referee their cases and the patients could also be referred to dentists to finish their treatment procedures. Early intervention with proper right management of TDI changes the outcomes and prognosis, all the GDPs should be trained to efficiently manage the traumatic events. That's why further studies on the effect of educational program trauma management courses on clinicians' knowledge that could be totally or partially fund from the Egyption menestry of health $(\mathrm{MOH})$ are suggested so that such courses can be extended for all the GDPs. Training and educational TDI management programs are recommended to become obligatory studies in graduation year for all speciallities and mandatory for promoting in any work for all community categories.

\section{CONFLICT OF INTEREST}

The authors declare no conflict of interest.

\section{FINANCIAL SUPPORT AND SPONSORSHIP}

No funding was received for this study.

\section{REFERENCES}

1. Firmino RT, Siqueira MB, Vieira-Andrade RG, Gomes GB, Martins CC, Paiva SM, et al. Prediction factors for failure to seek treatment following traumatic dental injuries to primary teeth. Braz Oral Res. 2014; 28:1

2. Lenherr P, Allgayer N, Weiger R, Filippi A, Attin T, Krastl G. Tooth discoloration induced by endodontic materials: a laboratory study. Int Endod J. 2012; 45:942-9.

3. Fux-Noy A, Sarnat H, Amir E. Knowledge of elementary school teachers in Tel-Aviv, Israel, regarding emergency care of dental injuries. Dent Traumatol.2011; 27: 252-6.

4. Berger R, Gelkopf M, Heineberg Y, Zimbardo. A schoolbased intervention for reducing posttraumatic symptomatology and intolerance during political violence.J of Educational Psychology. 2016; 108:761-71.

5. Frujeri Mde L, Frujeri JA, Bezerra AC, Cortes MI, Costa ED Jr: Socio-economic indicators and predisposing factors associated with traumatic dental injuries in schoolchildren at Brasilia, Brazil: a cross-sectional, population-based study. BMC Oral Health.2014; 14: 91.

6. SPINAS E. Dentoalveolar traumatology in pediatric dentistry. Pediatric Dentistry 2nd ed. 2020.

7. Cagetti MG, Marcoli PA, Berengo M, Cascone P, Cordone L, Defabianis $\mathrm{P}$, et al. Italian guidelines for the prevention and management of dental trauma in children. Ital $\mathrm{J}$ Pediatr. 2019; 45:157. 
8. Akhlaghi N, Nourbakhsh N, Khademi A, Karimi L. General dental practitioners' knowledge about the emergency management of dental trauma. Iranian Endo J.2014; 9:251-6.

9. Yeng T, O'Sullivan AJ, Shulruf B. A proposal to introduce dental trauma into medical education: An insight. Dent Traumatol. 2020; 36:390-2.

10. Duruk G, Erel ZB. Assessment of Turkish dentists' knowledge about managing avulsed teeth. Dent Traumatol. 2020; 36:371-81.

11. Resmy N, Parvathy K, Arun XM, Balagopal V. Knowledge, attitude, and awareness of mothers toward emergency management of dental trauma in high literacy population. J Int Oral Health. 2019; 11:287-92.

12. Kaul R, Jain P, Angrish P, Saha S, Patra TK, Saha N, et al. Knowledge, awareness and attitude towards emergency management of dental trauma among the parents of Kolkata.An institutional study. J Clin Diagn Res. 2016;10:95-101.

13. Bakarčić D, Hrvatin S, Maroević M, Ivančić Jokić N. First aid management in emergency care of dental injuries knowledge among teachers in Rijeka, Croatia. Acta Clin Croat. 2017; 56:110-6.

14. Akhlaghi N, Nourbakhsh N, Khademi A, Karimi L. General dental practitioners' knowledge about the emergency management of dental trauma. Iran Endod J. 2014; 9:251-6.

15. Tewari N, Sultan F, Mathur VP, Rahul M, Goel S , Bansal $\mathrm{K}$, et al.Global status of knowledge for prevention and emergency management of traumatic dental injuries in dental professionals. Systematic review and meta-analysis. Dent Traumatol. 2021; 37:161-76.

16. Wang G, Wang C, Qin M. A retrospective study of survival of 196 replanted permanent teeth in children. Dent Traumatol. 2019; 35:251-8.

17. Alluqmani FA, Omar OM. Assessment of schoolteachers' knowledge about management of traumatic dental injuries in Al-Madinah city, Saudi Arabia. Eur J Dent. 2018; 12:171-5.

18. Andersson L, Andreasen JO, Day P, Heithersay G, Trope $\mathrm{M}$, Diangelis AJ, et al; International association of dental traumatology. International sssociation of dental traumatology guidelines for the management of traumatic dental injuries: 2. Avulsion of permanent teeth. Dent Traumatol. 2012; 28:88-96.
19. Pujita C, Nuvvula S, Shilpa G, Nirmala S, Yamini V. Informative promotional outcome on school teachers' knowledge about emergency management of dental trauma. J Conserv Dent.2013; 16:21-7.

20. Ningthoujam S, Gurunathan D, Singh WR, Mall BB. Parental self-perceived knowledge and attitudes toward emergency management of avulsed permanent teeth in Imphal: A cross-sectional study. Natl J Maxillofac Surg. 2019; 10:33-42.

21. Andreasen JO, Lauridsen E, Gerds TA, Ahrensburg SS. Dental trauma guide: A source of evidence-based treatment guidelines for dental trauma. DentTraumatol 2012; 28:345-50.

22. Wu TT, Li JY, Yang KY, Wang PX, Yuan JX, Guo QY,et al. A cross-sectional evaluation of knowledge among Chinese dentists regarding the treatment of traumatic injuries in primary teeth. Dent Traumatol. 2021; 37:188-95.

23. Tzanetakis GN, Tzimpoulas N, Markou M, Papanakou SI, Gizani S, Georgopoulou M. Evaluating the knowledge level, attitudes, and therapeutic approaches of Greek dentists for traumatic dental injuries. Dent Traumatol. 2021; 37:177-87.

24. Al-Haj Ali SN, Algarawi SA, Alrubaian AM, Alasqah AI. Knowledge of General Dental Practitioners and Specialists about Emergency Management of Traumatic Dental Injuries in Qassim, Saudi Arabia. Int J Pediatr. 2020;2020:1-7

25. AlJazairy YH, Halawany HS, AlMaflehi N, Alhussainan NS, Abraham NB, Jacob V. Knowledge about permanent tooth avulsion and its management among dentists in Riyadh, Saudi Arabia. BMC Oral Health. 2015; 15:135 .

26. Chailertvanitkul P, Paphangkorakit J, Sooksantisakoonchai N, Pumas N, Pairojamornyoot W, Leela-Apiradee N, et al. Randomized control trial comparing calcium hydroxide and mineral trioxide aggregate for partial pulpotomies in cariously exposed pulps of permanent molars. Int Endod J. 2014; 47:835-42.

27. Cauwels RG, Martens LC, Verbeeck RM. Educational background of Flemish dental practitioners and their perceptions of their management of dental trauma. Dent Traumatol, 2014; 30: 133-9 .

28. Souza GL de, Azevedo PC, Rangel Éder F, Carvalho LP, Oliveira Mavec de, Moura CCG. Traumatic dental injures on maxillary incisors and its sequelae after 22-years follow-up: A case report. RSD [Internet]. 2020;9:10774. 
29. Girelli CF, de Lima CO, Lacerda MF, Coellho RG, Silveira FF, Nunes E. The importance of bioceramics and computed tomography in the late clinical management of a horizontal root fracture: A case report. J Clin Exp Dent. 2020;12:514-8.

30. Alghamdi NS. Management of traumatically intruded permanent maxillary central incisors. Saudi Endod J. 2020; 10:69-73.

31. Zhao Y, Gong Y. Knowledge of emergency management of avulsed teeth, a survey of dentists in Beijing, China. Dent Traumatol.2010; 26:281-4.

32. Limbu S, Dikshit P, Bhagat T, Mehata S. Knowledge of dental interns towards emergency management of avulsed tooth in dental colleges in Nepal. J of Nepal Health Research Council. 2014, 12:I-II

33. Çinar Ç, Atabek D, Alacam A. Knowledge of dentists in the management of traumatic dental injuries in Ankara, Turkey. Oral Health Prev Dent, 2013, 11.1: 23-30.

34. Shahhen N, Waly N, Elshaikh M. Evaluation of knowledge-Attitude-Practice (KAP) of Intern Dentists in Emergency Management of Traumatic dental Injuries in Permanent Anterior teeth. Egy Dent J, 2021, 67:79-84.

35. Bourguignon C, Cohenca N, Lauridsen E, Flores MT, O'Connell AC, Day PF, et al. International association of dental traumatology guidelines for the management of traumatic dental injuries: 1. Fractures and luxations. Dent Traumatol. 2020; 36:314-30.

36. Fouad AF, Abbott PV, Tsilingaridis G, Cohenca N, Lauridsen E, Bourguignon C, et al. International association of dental traumatology guidelines for the management of traumatic dental injuries: 2. Avulsion of permanent teeth. Dent Traumatol. 2020; 36:331-42. 